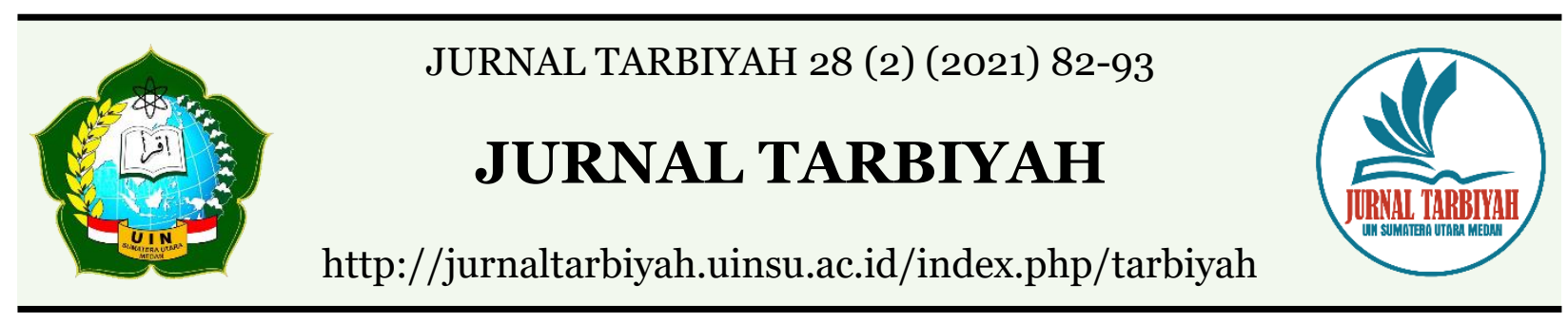

\title{
EFL TEACHER'S PEDAGOGICAL BELIEFS IN TEACHING AT AN INDONESIAN UNIVERSITY
}

\author{
Diah Safithri Armin'1, Ayu Meita Puteri Siregar² \\ ${ }^{1}$ Universitas Islam Negeri Sumatera Utara, Medan, Indonesia \\ ${ }_{2}^{2}$ Sekolah Tinggi Agama Islam Negeri Mandailing Natal, Mandailing Natal, Indonesia \\ Email: ${ }^{1}$ diahsafithriarmin@uinsu.ac.id, ${ }^{2}$ ayumeitaputeri@stain-madina.ac.id
}

DOI : 10.30829/tar.v28i2.1119

Accepted: October 9th, 2021. Approved: December 28th, 2021. Published: December 30th, 2021

\begin{abstract}
Teachers should have pedagogical beliefs in their studies, which function as a filter and guidance for their decision-making and teaching methods in the teaching-learning process. To promote an active and meaningful learning experience, Indonesian curriculum policy incorporated principles that place students at the center of the learning process. However, most of the time, teachers are in charge of the teaching-learning process and become the center of the learning process, while students are passive recipients of knowledge.This study was conducted to find out teachers' pedagogical beliefs in teaching at university. The present study was a basic interpretative qualitative study with five English teachers as the participants, and the data were collected through observation, questionnaire, and field notes. The data were analysed by data reduction, data display, and concluding. The study results showed that the teachers believed that teaching is the process of transmitting and constructing knowledge. This study implied that the EFL teachers believed and implemented a student-centered approach in the teaching-learning process.
\end{abstract}

Keywords: Role of School Principals, Teacher Performance Improvement 


\section{INTRODUCTION}

Since pedagogical beliefs function as a guide and filter for the teacher's choice and classroom instruction, instructors should have pedagogical beliefs about how to teach successfully and how students should learn. To provide students with active and meaningful learning experiences, the focus of teaching-learning processes should be on the students, with teachers serving as facilitators and mentors. Students should actively participate in teaching-learning processes. The Indonesian curriculum concentrates on the teaching-learning processes of the students in order to achieve this goal.

Teachers' beliefs have been found to influence how teacher approaches knowledge provided in teacher professional development programs and how they use it in their classrooms (Fives \& Buehl, 2012). Kumaravadivelu (2012) claims that belief functions as a filtering process through which new occurrences and experiences are screened, absorbed, and interpreted. Teachers' ideas and behaviors are also mutually informative, with contextual circumstances mediating the interaction between them (Song, 2014). Meanwhile, According to Shavelson and Stern, teachers' beliefs can impact how they make instructional decisions, choose resources, and select specific approaches or instructional practices (cited in Utami, 2016), roles, their objectives, methods, classroom interaction patterns, and students (Kuzborska, 2011). Calderhead (1996) classified these beliefs into five domains: teacher's beliefs in learner and learning, teaching, subject matter, learning to teach, and self and teaching role. However, a pedagogically-based concept of teachers' beliefs is different from other types of beliefs (Pajares, 1992) in which pedagogy focuses on the relationship between teaching and learning as well as how it produces knowledge and understanding.

Considering pedagogical beliefs as the teacher's guide in the teaching performances, the RISTEKDIKTI policy on implementing constructivist belief in teaching-learning process but opposite in reality, and previous studies which is still less in discussing English teachers' pedagogical beliefs in teaching at university in Indonesia, this study was conducted to find out "what do English teachers' pedagogical beliefs in teaching and learning refer to at university?". The scope of this study was in teachers' pedagogical beliefs in teaching and their teaching approach. The study results are expected to be beneficial for both theoretical and practical as well as a reflection and input for the readers' and teachers' pedagogical beliefs in improving their professionalism and producing effective and efficient teaching-learning process. 


\section{LITERATURE REVIEW}

Beliefs in teaching refer to teachers' beliefs in the purposes of teaching, teaching as a process of transmitting knowledge or facilitating learning (Calderhead, 1996). If teaching is transmitting knowledge, the teacher is the teller of the truth and the controller of the classroom environment and students' behavior, while the students are the passive actors who listen to their teacher and do the exercise. This belief is called traditional beliefs. Then, this belief was challenged by another belief which is called constructivist belief. Constructivist belief changes the teacher to be a facilitator of the student's needs in the learning process, and the students act as an active actors who should give their effort in understanding the material.As a result, instructors will encourage active learning through peer interaction and self-reflection, as well as respond quickly in determining what and how the learning process will take place (Wong et al., 2009). Teachers who believe in teaching as the transfer of knowledge will use a content-oriented approach as a teaching technique, whereas teachers who believe in teaching as active and meaningful learning experiences will use a constructivist approach.

The term "preconceptions language learners have about the task of learning the target language" refers to "beliefs language learners have about the process of learning the target language" (Huang, 1997, p. 29 cited in Abdi \&Asadi, 2015). The phrases "opinions," "ideas," and "views" all relate to "beliefs" (Kunt \& Wang cited in Abdi \&Asadi, 2015). Calderhead (1996) offers another definition of beliefs in learning, arguing that these views are related to instructors' ideas about how their students learn, and therefore these beliefs will affect the teachers' teaching task approaches and the connection between teachers and students.

The teachers' views in learning may be summarized as their beliefs on how their pupils learn. These ideas will aid teachers in determining how learning will take place, the appropriate methods for implementation, and how they should interact with pupils. The transmission and constructivist beliefs in learning are the same as the transmission and constructivist beliefs in teaching. According to transmission beliefs, learning is viewed as a process of obtaining information, with the instructor as the transmitter and the students as the passive receiver.Teachers are seen as facilitators by constructivists, while students are seen as active participants. As a result, this study will combine Calderhead's (1996) definition of learning beliefs as the teacher's beliefs about how his students learn, which influence the teacher's teaching approaches and the relationship between teacher and students, with Johnson's (2001) views on language and language learning. 
Constructivist belief, then, is adapted in the Indonesian higher education curriculum (RISTEKDIKTI, 2016) that sees the students as the focus of the learning process and becomes one of the national standard principles to create an active and meaningful learning experience for the students. However, most of the time, the English teachers in Indonesia are still authoritative in managing the whole teaching-learning process. The students passively receive the knowledge, especially at university, where the teachers consistently implement lecturing techniques and a teacher-oriented approach.

Many kinds of research have been conducted on teachers' pedagogical beliefs. This research can provide meaningful input and reflection to improve teachers' performance in teaching and to learn English. Research by TALIS (2009) in some European countries found two kinds of pedagogical beliefs implemented in the teaching-learning process in western countries, namely transmission and constructivist beliefs. Khader (2012), which involved 21 teachers and 529 students, figured out the relationship between the teachers' pedagogical beliefs and their teaching performance from the students' perspective, and it showed that there is no significant correlation between teachers' beliefs and their teachingperformance. Then, Uddin (2014), who investigated teachers' belief in teaching writing by involving fifteen private university teachers, found that their beliefs and teaching in the classroom were inconsistent. Other research by Larenas, Hernandez, and Naverrete (2015) found seven categories of teachers' belief in teaching and learning English: the use of English in the lesson; the teacher's role; the student's role; teaching components; the role of teaching and learning context; the role of language curriculum; and the relation between language curriculum and course-book content. However, there is still limited research that focuses on English teachers' pedagogical beliefs in teaching at universities in Indonesia.

\section{RESEARCH METHOD}

This study applied basic interpretative qualitative method due to its purpose to reveal the teacher's pedagogical beliefs in teaching since belief relates to "attitude, values, judgments, axioms, opinions, ideology, perceptions, conceptions conceptual systems, preconceptions, dispositions, implicit theories, explicit theories, personal theories, internal mental processes, action strategies, rules of practice, practical principles, perspectives, repertories of understanding, and social strategy" (Pajares, 1992, p. 309). Thus, the data of this study was teachers' perception and perspective on how to teach English and their role as English teachers in teaching English. 
This research was conducted in one of the State Universities in Indonesia. Two fundamental reasons for choosing this site were its convenience and accessibility, and the second was its development. Alwasilah (2009) suggests that the convenience factor is one factor that the researcher should consider in deciding the research site due to supporting the researcher in collecting data. The research site was the researcher's undergraduate university, so it gives easy access to the researcher get permission in doing research and collecting data. Then, this research site is a university that has developed from institute to university in 2014. To support this development, the university has increased its quality, including the teachers; hence, the researcher was interested in finding out the English teachers' pedagogical beliefs in teaching at this university.

The participant of this study was four English teachers in English department. These teachers were chosen based on their teaching experiences and teaching skill. The first and the second teacher are male teachers who have taught for 15 years, and one of them is a favorite teacher based on a questionnaire distributed to the English department students. The third teacher is a female teacher who has taught for more than 20 years at this university. The fourth teacher is a male teacher who has taught for more than five years. The last teacher is a female teacher who has taught for more than five years and was chosen as the favorite teacher.

The data were collected through a closed-ended questionnaire, observation checklist, and field note. To keep the trustworthiness of the data, all of these instruments were triangulated to find out the teachers' perspectives on how to teach English and their teaching approach in teaching-learning process. Then, the data were analysed by implementing three steps: data reduction, data display, and drawing conclusions (Alwasilah, 2009; Miles \& Huberman in Malik \& Hamied, 2014).

\section{RESULTS}

Based on the data analysis, the EFL teachers believe teaching is transmitting knowledge as well as constructing knowledge. In addition, the EFL teachers applied a student-centered approach in their teaching practice.

\section{Transmitting Knowledge}

To explore teachers' belief in teaching as a transmitting process, the researcher used a questionnaire consisting of ten statements. The results of the questionnaire can be seen in the table as follows: 
Table 1. Percentage of EFL Teachers' Belief in Teaching as Transmitting Knowledge

\begin{tabular}{|c|l|c|c|c|c|}
\hline No. & Statement & $\begin{array}{l}\text { Strongly } \\
\text { Agree }\end{array}$ & Agree & Disagre & $\begin{array}{c}\text { Strongly } \\
\text { Disagree }\end{array}$ \\
\hline 1. & $\begin{array}{l}\text { The teaching-learning process is a } \\
\text { process of transmitting knowledge. }\end{array}$ & $80 \%$ & $20 \%$ & $0 \%$ & $0 \%$ \\
\hline 2. & $\begin{array}{l}\text { The teacher establishes learning goals } \\
\text { and the rules of conduct for the } \\
\text { students. }\end{array}$ & $80 \%$ & $20 \%$ & $0 \%$ & $0 \%$ \\
\hline 3. & $\begin{array}{l}\text { Asking the students to prepare } \\
\text { themselves well for every meeting. }\end{array}$ & $80 \%$ & $20 \%$ & $0 \%$ & $0 \%$ \\
\hline 4. & $\begin{array}{l}\text { I control the students' behavior and } \\
\text { classroom environment. }\end{array}$ & $0 \%$ & $100 \%$ & $0 \%$ & $0 \%$ \\
\hline 5. & $\begin{array}{l}\text { I manage the learning activities and } \\
\text { the duration of every learning } \\
\text { segment. }\end{array}$ & $80 \%$ & $20 \%$ & $0 \%$ & $0 \%$ \\
\hline 6. & $\begin{array}{l}\text { I am the resource of the knowledge in } \\
\text { the classroom. }\end{array}$ & $0 \%$ & $80 \%$ & $20 \%$ & $0 \%$ \\
\hline 7. & $\begin{array}{l}\text { I teach the materials by using the } \\
\text { local-produced materials. }\end{array}$ & $0 \%$ & $80 \%$ & $20 \%$ & $0 \%$ \\
\hline 8. & $\begin{array}{l}\text { I give the exercise after presenting the } \\
\text { materials. }\end{array}$ & $0 \%$ & $80 \%$ & $20 \%$ & $0 \%$ \\
\hline 9. & $\begin{array}{l}\text { The students' achievements are based } \\
\text { on their test scores. }\end{array}$ & $80 \%$ & $80 \%$ & $0 \%$ & $0 \%$ \\
\hline 10. & $\begin{array}{l}\text { I explain the materials clearly while } \\
\text { the students only listen to my } \\
\text { explanation. }\end{array}$ & $20 \%$ & $0 \%$ & $60 \%$ & $20 \%$ \\
\hline
\end{tabular}

The first statement asks whether teachers believe teaching as transmitting knowledge, and $80 \%$ of the teachers strongly agreed, and $20 \%$ agreed, which shows that all the participants agreed to teach as transmitting knowledge. It means that the EFL teachers see themselves as the sources of the knowledge and the students as the passive actors who receive knowledge from the teachers. 
The second statement asks whether the participant formulated the rules and learning goals by themselves, and the participant $80 \%$ strongly agreed, and 20\% agreed they established the rules and learning goals. It indicates that the EFL teachers have full authority in formulating the rules and learning goals. It was confirmed by the data from field notes which showed how the EFL teachers determine the students' attitude in the classroom.

The third statement asked if the EFL teachers ask their students to prepare themselves before coming to the class in every meeting, and $80 \%$ of participants strongly agreed, and $20 \%$ agreed. It showed that the EFL teachers hoped their students read some sources so they have prior knowledge and could easily follow the lesson in the classroom.

The fourth statement was about controlling students' behavior and classroom environment, and the participants $100 \%$ agreed. By $100 \%$, participants agreed to this statement indicates that the EFL teachers are the controller of the student's behavior and the manager of the learning environment. The EFL teachers have high expectations of how the learning process has to be suitable to their plans.

The fifth statement is about managing learning activities and the duration of learning segments. $80 \%$ of participants strongly agreed, and $20 \%$ agreed that they manage learning segments' learning activity and duration. These percentages were suitable to the percentage in the second statement in which the EFL teachers set the learning goals by themselves, so it means the EFL teachers have to manage the learning activity and learning duration by themselves.

The sixth statement asked whether the EFL teachers see themselves as the source of the knowledge in the learning process, and only $80 \%$ of participants agreed. It means that the EFL teachers want their students to acquire knowledge from various sources and confirm their perception that they should prepare well before coming to the classroom.

The seventh statement was about teaching material by using locally produced material. $80 \%$ of participants agreed that they use locally produced material. It indicated that the EFL teachers also use other sources, which is in line with their perception in the previous statements that they ask the students to find the material from other sources.

The eighth statement was about giving exercise after explaining the materials, and $80 \%$ of participants agreed while the rest chose to disagree. This finding is quite interesting where some of the participants chose disagreed with giving exercise while one of the learning processes should be evaluated. The researcher confirmed this statement by interviewing the participant's reason for choosing to disagree. In her perception, it is 
not necessary to give the students exercise after presenting the material. Exercise could be changed to be a class discussion or practicing the material because learning English means learning a language, and a language is a communication tool. For example, when the material is about giving an opinion orally, the best step after explaining the material is to ask the students to give their opinion on a determined topic.

The following statement was about students' achievements is based on their scores. For this statement, $20 \%$ of the participants strongly agreed, and $80 \%$ agreed. It indicates that all the EFL teachers use the students' scores as the parameter of students' achievement.

The last statement was about the EFL teachers explain the material and the students only listen to it. Among other statements, this statement had a different result in which the participant $20 \%$ strongly agreed, 60\% disagreed, and 20\% strongly disagreed. This percentage indicated that the EFL teachers believe that the teaching-learning process is a transmitting knowledge process, but it does not mean that the students only listen to their teachers passively; they also need to perform their roles actively.

All these findings cross-checked through semi-structured interview to the participants and were reflected in the teaching-learning process which were noted in the observation sheet. Thus, the EFL teachers believe teaching is transmitting knowledge from the teacher to students.

\section{Constructing Knowledge}

In the same questionnaire, the researcher provided ten statements about teaching as constructing knowledge, and the results can be seen in the table as follows:

Table 2. The Percentage of Teachers' Belief in Teaching as Constructing Knowledge

\begin{tabular}{|c|l|c|c|c|c|}
\hline No. & Statement & $\begin{array}{l}\text { Strongly } \\
\text { Agree }\end{array}$ & Agree & Disagree & $\begin{array}{c}\text { Strongly } \\
\text { Disagree }\end{array}$ \\
\hline 1. & $\begin{array}{l}\text { Teaching-learning process is a } \\
\text { process of constructing knowledge. }\end{array}$ & $60 \%$ & $40 \%$ & $0 \%$ & $0 \%$ \\
\hline 2. & $\begin{array}{l}\text { The teacher is a facilitator of the } \\
\text { students' needs. }\end{array}$ & $0 \%$ & $60 \%$ & $40 \%$ & $0 \%$ \\
\hline 3. & $\begin{array}{l}\text { Asking the students to find the } \\
\text { information from the other resource. }\end{array}$ & $60 \%$ & $40 \%$ & $0 \%$ & $0 \%$ \\
\hline 4. & Using authentic teaching materials. & $100 \%$ & $0 \%$ & $0 \%$ & $0 \%$ \\
\hline
\end{tabular}


Diah Safithri Armin, Ayu Meita Puteri Siregar / JURNAL TARBIYAH 28 (2) (2021) 82-93

\begin{tabular}{|c|l|c|c|c|c|}
\hline 5. & $\begin{array}{l}\text { Implementing role-play and group } \\
\text { work as the teaching techniques. }\end{array}$ & $60 \%$ & $40 \%$ & $0 \%$ & $0 \%$ \\
\hline 6. & $\begin{array}{l}\text { Questioning the students and asking } \\
\text { them to answer it by discussing in a } \\
\text { small group. }\end{array}$ & $60 \%$ & $40 \%$ & $0 \%$ & $0 \%$ \\
\hline 7. & $\begin{array}{l}\text { Dividing the students into small } \\
\text { groups and asking them to present } \\
\text { some of the learning materials in } \\
\text { front of the classroom. }\end{array}$ & $20 \%$ & $40 \%$ & $40 \%$ & $0 \%$ \\
\hline 8. & $\begin{array}{l}\text { Assessing the students formally and } \\
\text { informally, such as presentation, } \\
\text { portfolio, group project, and their } \\
\text { participation in the classroom. }\end{array}$ & $100 \%$ & $0 \%$ & $0 \%$ & $0 \%$ \\
\hline 9. & $\begin{array}{l}\text { Assessing the students continuously } \\
\text { during the teaching-learning } \\
\text { processes. }\end{array}$ & $0 \%$ & $100 \%$ & $0 \%$ & $0 \%$ \\
\hline 10. & $\begin{array}{l}\text { The learning goals established } \\
\text { together (teacher and students) }\end{array}$ & $40 \%$ & $0 \%$ & $60 \%$ & $0 \%$ \\
\hline
\end{tabular}

In the first statement, the EFL teachers were 60\% strongly agree, and 40\% agree if they see teaching as a constructing knowledge process. They believe that the teacher is a facilitator in the learning process, and the students are the main actors. So, the learning process should be dominated by the students. This perception is confirmed in the second statement, which asks whether they consider themselves as a facilitator or not, and 60\% of the participants agreed while 40\% disagreed. Although only 60\% of the participant agreed, it showed that the EFL teachers believe teaching is the process of constructing knowledge.

Further, in the third and fourth statements, all the participants strongly agreed and agreed if they asked the students to find information or read other sources and prepare authentic material. It means that the EFL teachers do not consider themselves as the only source of knowledge. They try to provide the material authentically but still give a chance to the students to explore the knowledge from other sources.

Then, the fifth statement is about implementing role-play and group work as the teaching technique, and $60 \%$ of the participant strongly agreed, and $40 \%$ agreed. This 
result indicates that the EFL teachers fully see teaching as constructing knowledge in which constructive belief focuses on the students. So, it proves that these EFL teachers have firm constructivist beliefs.

In the sixth and seventh statements, the researcher focused on the EFL teachers' teaching techniques. In the sixth statement, the EFL teachers, 60\% strongly agree, and $40 \%$ agree that they give a question and ask the students to answer it in a small group. However, in the seventh statement, the EFL teachers, 20\% strongly agree, $40 \%$ agree, and $40 \%$ disagree that they ask the students do a group presentation. $40 \%$ of the participants disagree, which showed that the EFL teachers prefer to do brainstorming and make the students be active on the spot directly rather than make the students do a presentation that perhaps some of the group members do not contribute.

Next, the eighth and ninth statement focus on how the EFL teachers assess the students' achievement. The EFL teachers 100\% strongly agree that they assess the students formally and informally, and $100 \%$ agree that they continuously assess their students. It indicates that the EFL teachers keep watching their students' progress and every progress affects their evaluation.

The last statement of this questionnaire is about establishing the learning goals. Only $40 \%$ of the EFL teachers strongly agreed that they established with the students, while the rest disagreed. It means that the EFL teachers account that determining learning goals is the teachers' right. This finding is not surprising since all the EFL teachers strongly agree and agree that they established the learning goals in the transmitting knowledge questionnaire.

These findings were confirmed to the EFL teachers through semi-structured interviews and observation. Thus, it could be concluded that these EFL teachers have firm constructivist beliefs.

Pedagogical teaching beliefs are divided into two kinds: transmission belief and constructivist beliefs (Calderhead, 1996). Based on the finding, all of the participants have both of these beliefs. TALIS (2009) also found a similar research finding in European countries in which constructivist and transmission beliefs are implemented together. Nevertheless, in this research, the EFL teachers have a higher percentage of constructivist belief than transmission belief. Besides, this finding was apposite to Khader's (2012) and Udin's (2014) research findings that showed there is no significant relationship between EFL teachers' beliefs and their performance. In contrast, the present study participants showed that they implement what they believe in their teaching in the classroom. 


\section{CONCLUSION}

This study was conducted to find the EFL teachers' beliefs in teaching at University in Indonesia based on the Indonesian Higher Education Curriculum, which adapted constructivist belief, but the reality shows contrast conditions. The results showed that the EFL teachers have constructivist beliefs and transmission beliefs in which teaching transmits knowledge and facilitating the students' needs and learning activities. They combined these beliefs and applied them in the teaching-learning process.

In teaching English, the participants choose behaviorist and mentalism/rationalism. They believe if teaching English should be a habit process. Therefore, during the learning process, the teachers and the students speak English. Furthermore, the teachers believe that their role in the classroom is as controller, director, manager, facilitator, prompter, tutor, and resource. Thus, they implement a studentcentered approach, so the students have a big responsibility in the learning process.

This research involved five EFL teachers due to specific reasons. For further research, it recommends involving a more significant number of EFL teachers chosen randomly to figure out the EFL teachers' beliefs in teaching deeper.

\section{REFERENCES}

Alwasilah, A. C. (2009). Pokoknya kualitatif. Jakarta: Dunia Pustaka Jaya.

Abdi, H., \& Asadi, B. (2015). A Synopsis of Researches on Teachers' and Students' Beliefs about Language Learning. International Journal on Studies in English Language and Literature (IJSELL), 3(4), 104-114.

Calderhead, J. (1996). Teachers: beliefs and knowledge. In D. C. Berliner, \& R. C. Calfee (Eds.), Handbook of Educational Psychology (pp. 709-725). New York: Macmillan.

Fives, H., \& Buehl, M. M. (2012). Spring cleaning for the "messy" construct of teachers'beliefs: What are they? Which have been examined? What can they tell us? APA Educational Psychology Handbook, 2, 471-499.

Johnson, K. (2001). Learning about language: An introduction to foreign language learning and teaching. Harlow, England: Pearson Education Limited.

Khader, F. R. (2012). Teachers' pedagogical beliefs and actual classroom practices in social studies instruction. American International Journal of Contemporary Research, 2(1), 73-92. 
Kumaravadivelu, B. (2012). Language teacher education for a global society: A modular model for knowing, analyzing, recognizing, doing, and seeing. Routledge.

Kuzborska, I. (2011). Links between teachers' beliefs and practices and research on reading. Read. a Foreign Lang, 23(1), 102-128.

Larenas, C. D., Hernandez, P. A., \& Navarrete, M. O. (2015). A Case Study on EFL Teachers' Beliefs About the Teaching and Learning of English in Public Education. Porta linguarum, 23, 171-186.

Malik, R. S., \& Hamied, F. A. (2014). Research methods: A guide for first time researchers. Bandung: UPI Press.

Pajares, F. (1992). Teachers' beliefs and educational research: Cleaning up a messy construct. Review of educational research, 62, 307-332.

RISTEKDIKTI. (2016). Panduan penyusunan kurikulum pendidikan tinggi (2nd ed.). Jakarta: Direktorat Jenderal Pembelajaran dan Kemahasiswaan Kementerian Riset Teknologi dan Pendidikan Tinggi.

Song, S. Y. (2014). Teacher's beliefs about language learning and teaching. In M. Bigelow \& J. Ennser-Kananen (Eds.), The Routledge Handbook of Educational Linguistics (1st ed., pp. 263-275). Routledge.

TALIS. (2009). Creating effective teaching and learning environments. OECD. Retrieved from www.oecd.org/berlin/43541655.

Uddin, M. E. (2014). Teachers' pedagogical belief and its reflection on the practice in teaching writing in EFL tertiary context in Bangladesh. Journal of Education and Practice, 5(29), 116-129.

Utami, D.N. (2016) The EFL Teachers' Beliefs and Their Teaching Practices. OKARA J. Bhs. dan Sastra, 10 (2), 135.

Wong, A. K., Chan, K-W., \& Lai, P-Y. (2009). Revisiting the relationships of epistemic beliefs and conceptions about teaching and learning of pre-service teachers in Hong Kong. The Asia-Pacific Education Researche, 18(1), 1-19. 